Jurnal Penelitian Humano, Vol. 9 No. 2 Edisi November 2018

\title{
STRATEGI PENGEMBANGAN WILAYAH PERBATASAN PULAU MOROTAI DALAM MEMACU PERTUMBUHAN EKONOMI DI PROVINSI MALUKU UTARA
}

\author{
MUHAMMAD HASNIN \\ Prodi Ekonomi Pembangunan, Fakultas Ekonomi dan Bisnis,UNKHAIR \\ Email : mhasnin.feb@gmail.com
}

\begin{abstract}
ABSTRAK. Penelitian ini bertujuan untuk merumuskan strategi untuk mengembangkan wilayah perbatasan Pulau Morotai dalam hal pembangunan ekonomi. Temuan penelitian ini diharapkan menjadi arahan yang lebih spesifik terhadap pengembangan potensi ekonomi Morotai dalam perumusan strategi yang mendukung kebijakan pemerintah. Implikasi dari pengembangan daerah perbatasan juga ditinjau dari pendekatan terhadap elemen praktik terbaik dan studi teoritis dalam konteks pengembangan wilayah perbatasan, yang kemudian menjadi input untuk perumusan strategi. Pendekatan kuantitatif dalam penelitian ini bermaksud untuk menjelaskan variabel-variabel penelitian yang disintesis dari literatur mengenai pertumbuhan ekonomi di wilayah perbatasan. Triangulasi serentak digunakan untuk melengkapi hasil penelitian secara kualitatif dan kuantitatif pada analisis antar dan intraregional. Analisis dalam penelitian ini adalah spasial, struktur ekonomi, serta analisis deskriptif kuantitatif dan kualitatif). Temuan penelitian ini membuktikan bahwa pertumbuhan ekonomi di Pulau Morotai memiliki peluang dalam mengembangkan daerah perbatasan karena wilayah ini memiliki modal dasar yang penting dalam pengembangan wilayah perbatasan, yaitu unsur budaya, kerangka kerja kelembagaan, kepentingan sektor swasta, infrastruktur, kebijakan, dan pendekatan investasi . Kendala pada pengembangan perbatasan dalam perspektif ekonomi ini adalah peran kebijakan dan infrastruktur yang belum mendukung pengembangan wilayah perbatasan. Strategi pembangunan perbatasan termasuk mendorong peraturan yang kondusif dan operasional untuk menawar pembangunan ekonomi di daerah perbatasan, meningkatkan peran sektorsektor utama dan mendorong sektor-sektor lain dalam pertumbuhan, meningkatkan perhatian pada keberlanjutan pembangunan dan pengembangan sumber daya manusia.
\end{abstract}

ABSTRACT. This study aims to formulate a strategy for developing the Morotai Island border area in terms of economic development. The findings of this study are expected to be a more specific direction towards the development of Morotai's economic potential in the formulation of strategies that support government policy. The implications of developing border areas are also reviewed from approaches to elements of best practice and theoretical studies in the context of border area development, which then becomes input for strategy formulation. The quantitative approach in this study intends to explain the research variables synthesized from the literature regarding economic growth in the border region. Concurrent triangulation is used to complement the results of the study qualitatively and quantitatively on inter and intraregional analysis. The analysis in this study is spatial area, economic structure, as well as quantitative and qualitative 
Jurnal Penelitian Humano, Vol. 9 No. 2 Edisi November 2018

descriptive analysis). The findings of this study prove that economic growth in Morotai Island has opportunities in developing border areas because this region has important basic capital in the development of border areas, namely elements of culture, institutional frameworks, private sector interests, infrastructure, policy and investment approaches. The constraints on border development in this economic perspective are the role of policies and infrastructure that have not supported the development of border areas. The border development strategies include encouraging regulations that are conducive and operational to bideng economic development in border areas, increasing the role of leading sectors and encouraging other sectors in growth, increasing attention to sustainability of development and human resource development.

Keywords: border area, economic growth, development strategy

\section{PENDAHULUAN \\ Latar Belakang}

Perhatian terhadap wilayah perbatasan dan implikasinya terhadap pertumbuhan ekonomi cenderung meningkat seiring dengan fungsi wilayah ini sebagai batas sumber daya. Kesempatan ekonomi tersebut muncul karena adanya pemanfaatan sumber daya di wilayah yang berbatasan dan kedekatannya secara spasial (Van Well, 2015; Niebuhr dan Stiller, 2011). Selain itu, meningkatnya peluang pertumbuhan ekonomi dipengaruhi oleh perubahan kondisi negara ke arah kerjasama dalam meningkatkan potensi kesempatan ekonomi. (Akahadan Vassilieva, 2015).

Peluang pertumbuhan ekonomi di wilayah perbatasan dimiliki oleh Pulau Morotai sangat menjanjikan. Kawasan ini merupakan kawasan ekonomi khusus, sesuai dengan PP No. 50 tahun 2014 tentang kawasan ekonomi khusus Pulau Morotai memiliki luas 1.101,76 Ha, terletak dalam wilayah Kecamatan Morotai Selatan, Kabupaten Pulau Morotai. Kawasan; c. Zona Industri; dan d. Zona Pariwisata. Pengembangan kawasan ini Ekonomi Khusus Morotai terbagi dalam a.Zona Pengolahan Ekspor; b. Zona Logistik akan mampu menciptakan investasi sebesar Rp 6,8 triliun untuk pembangunan kawasan, dan mampu menarik investasi sebesar $\mathrm{Rp}$ 30,44 triliun hingga 2025. Tenaga kerja yang terserap mencapai 30.000 orang. Jumlah kunjungan wisata manca negara 2014-2016 mencapai 1.557 orang, dan wisawan lokal sebanyak 10.336 orang. Namun hingga saat ini identifikasi dan analisis spasial wilayah perbatasan ditinjau dari penggunaan lahan, struktur ruang dan kependudukan; identifikasi dan analisis pertumbuhan ekonomi wilayah perbatasan; serta strategi pengembangan wilayah perbatasan Pulau Morotai belum terkonstruksi dalam sebuah kebijakan Pemerintah Daerah yang baik, sehingga penelitian ini dipandang tepat untuk dilakukan.

\section{Perumusan Masalah}

Permasalahan yang mendasari penelitian ini diawali dari terbentuknya Kawasan Ekonomi Khusus tahun 2014. Pulua Morotai yang ditetapkan sebagai KEK, menunjukkan peran kawasan perbatasan yang mengalami pergeseran prioritas dari pendekatan keamanan menjadi kesejahteraan. Berdasarkan kondisi tersebut, problem statement yang muncul adalah perlunya tinjauan terhadap pertumbuhan ekonomi wilayah KEK Pulau Morotai dalam rangka pengembangan perbatasan. Bertitik tolak dari problem statement, maka pertanyaan 
Jurnal Penelitian Humano, Vol. 9 No. 2 Edisi November 2018

penelitian/research question yang muncul adalah: "Bagaimanakah strategi pengembangan wilayah perbatasan Pulau Morotai dalam memacu pertumbuhan ekonomi?.

\section{Tujuan Penelitian}

Tujuan penelitian yang ingin dicapai adalah:

1. Melakukan identifikasi dan analisis spasial wilayah perbatasan Pulau Morotai ditinjau dari penggunaan lahan, struktur ruang dan kependudukan;

2. Melakukan identifikasi dan analisis perekonomian wilayah perbatasan Pulau Morotai;

3. Melakukan analisis pertumbuhan ekonomi dan pengembangan wilayah perbatasan;

4. Merumuskan strategi pengembangan wilayah perbatasan berbasis pada perspektif pembangunan ekonomi.

\section{Out put Penelitian}

Out put penelitian ini adalah:

1. Mengetahui kondisi spasial kawasan yang dilihat dari penggunaan lahan, struktur ruang, dan kependudukan Pulau Morotai

2. Mengetahui indikasi pertumbuhan ekonomi wilayah baik secara inter maupun intrawilayah Pulau Morotai

3. Mengetahui secara komprehensif mengenai pertumbuhan ekonomi kawasan perbatasan Pulau Morotai

4. Mengetahui strategi pengembangan wilayah perbatasan berbasis pada perspektif pembangunan ekonomi.

\section{Konstribusi terhadap Ilmu Pengetahuan}

Secara teoritis, penelitian ini berkonstribusi terhadap pengembangan akademik terutama pengembangan mata kuliah Ekonomi Regional, Perencanaan Pembangunan, Ekonomi Urban dan Tata
Ruang, yang berkaitan dengan model program pengembangan dan pemberdayaan masyarakat di Kabupaten Pulau Morotai Sebagai daerah Perbatasan

Konstribusi praktis penelitian ini yaitu sebagai alternatif model program pengembangan dan pemberdayaan ekonomi daerah perbatasan. Kontribusi ini terutama bagi pelaku usaha di sektor parawisata khusus, meski terbuka untuk semua aktivitas ekonomi secara umum.

\section{METODE PENELITIAN}

\section{Lokasi Penelitian}

Penelitian ini berlokasi di Kabupaten Pulau Morotai. Pertimbangan lokasi ini sebagai obyek penelitian didasarkan pada pertimbangan Kabupaten Pulau Morotai sebagai Daerah Kawasan Ekonomi Khusus (KEK) yang ditetapkan dengan keputusan Pemerintah Nomor 50 Tahun 2014, juga sebagai daerah perbatasan dengan beberapa negara (Jepangan, Tailan dan Australia) menjadikan Pulau Morotai Sebagai pintu kerbang ekonomi kawan ini. Pertimbangn ini menjadi alasan peneliti memilih lokasi penelitian ini.

\section{Jenis dan Sumber Data}

Jenis data yang digunakan dalam penelitian ini adalah data sekunder, dinataranya adalah:

1. Data Jumlah Penduduk 2014-2016;

2. Data PDRB Kabupaten Morotai dan PDRB Provinsi Maluku Utara 20142016;

3. Infrastruktur Ekonomi (Jalan, Listrik, Air Bersih, Telokomunikasi, Bandar Udara) 2014-2016;

4. Pendapatan Perkaita 2014-2016; dan data2 lain yang terkait dengan penelitian ini

5. Peta Kawasan Ekonomi Khusus (KEK)

6. Infastruktur Pendidikan, Kesehatan Seluruh data yang ada diusahakan 
Jurnal Penelitian Humano, Vol. 9 No. 2 Edisi November 2018

perolehannya di Kantor Statistik Kabupaten Pulau Morotai dan Statistik Provinsi Maluku Utara; Bappeda Kabupaten Pulau Morotai dan Bappeda Provinsi Maluku Utara; PU Kabupaten Pulau Morotai dan PU Provinsi Maluku
Utara, dan instansi lain yang dipandang terkait dengan kebutuhan data dalam penelitian. Data ini dikumpulkan dengan menggunakan format pengumpulan data yang disiapkan penelitisebelumnya.

\section{Prosedur Penelitian}

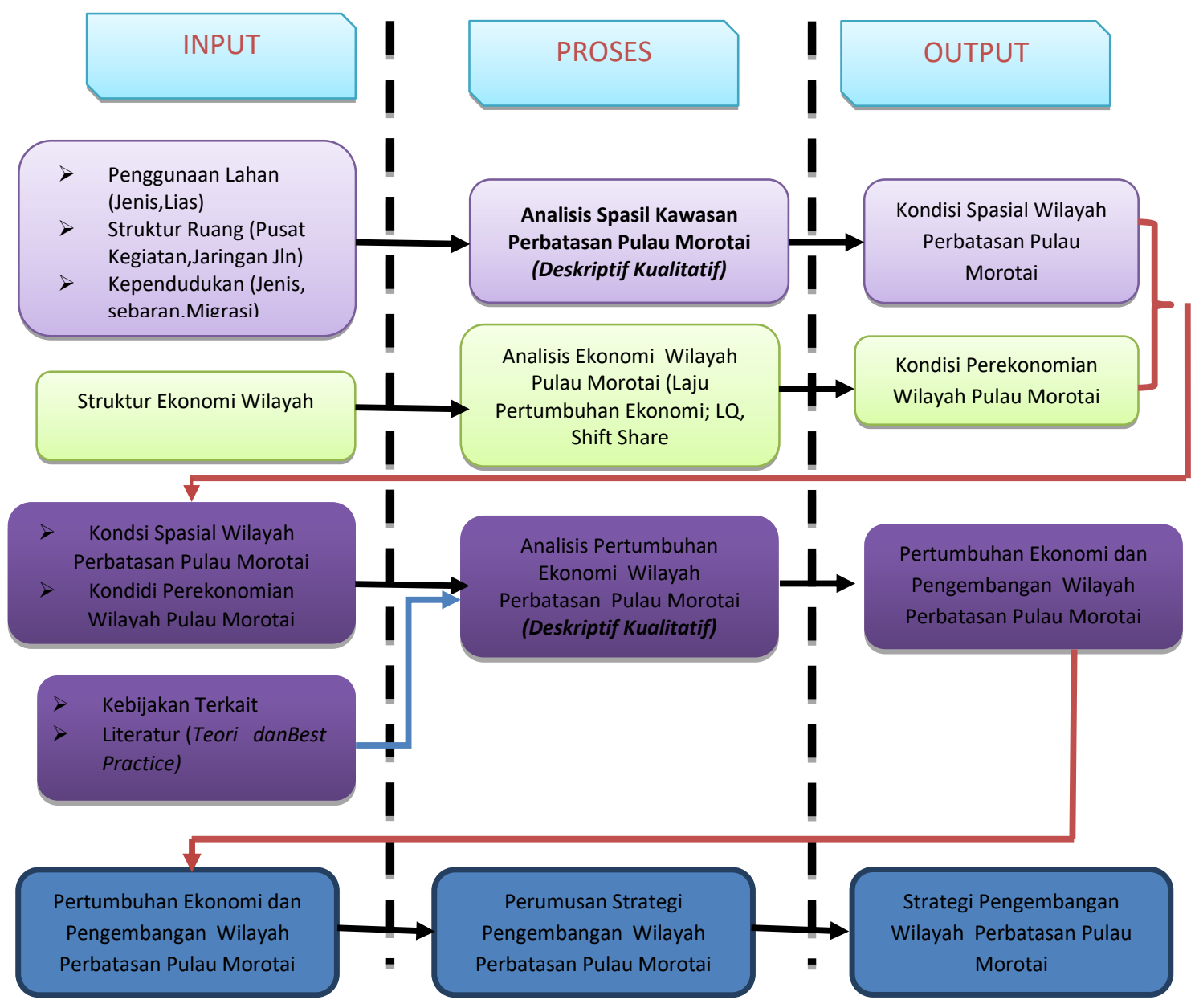

Teknik Analisis Data

Teknik analisis dalam penelitian ini terkait dengan pengukuran atas indikator ekonomi wilayah. Penggunaan teknik analisis ini terkait dengan konteks wilayah yang dilihat secara intra(antarwilayah), maupun inter(dalam wilayah) perbatasan Pulau Morotai. Beberapa teknik tersebut antara lain adalah laju pertumbuhan ekonomi, sektor basis ekonomi, kinerja sektor ekonomi, dan identifikasi sektor prioritas/unggulan.

\section{HASIL PENELITIAN DAN PEMBAHASAN}

Bagian ini membahas aspek pertumbuhan ekonomi wilayah perbatasan untuk perumusan strategi pengembangan. Bagian awal membahas aspek spasial dan ekonomi, selanjutnya 
Jurnal Penelitian Humano, Vol. 9 No. 2 Edisi November 2018

dibahas tentang implikasi elemen pengembangan yang akan digunakan dalam formulasi strategi pengembangan wilayah perbatasan ditinjau dari aspek pertumbuhandan pengembangan.

\section{Penggunaan lahan}

Berkaitan dengan pertumbuhan ekonomi diwilayah perbatasan, dinamika pertumbuhan ekonomi yang terjadi dapat menyebabkan adanya efek integrasi ekonomi yang diikuti oleh perubahan spasial diwilayah perbatasan (Niebuhr dan Stiller,2001). Kondisi spasial merupakan factor penting dalam melihat perkembangan sebuah wilayah perbatasan yang tercermin dari penggunaan lahan, struktur ruang dan aktivitas penduduk dalam ruang tersebut (Branch,1995). Perubahan yang terjadi pada beberapa aspek ini mengindikasikan pertumbuhan ekonomi diwilayah perbatasan Pulau Morotai.

Data penggunaan lahan tahun2014-2016 menunjukkan perubahan hanya terjadi pada daerah disepanjang jalur utama kawasan dan hanya pada daerah di Ibukota Kecamatan saja.
Perubahan terjadi pada perkembangan permukiman di jalur utama kearah perbatasan sebesar $0,15 \%$, sedangkan jenis pemanfaatan yang lain belum begitu berkembang.Hal ini karena beberapa fungsi kawasan sudah ditentukan sebagai kawasan ekonomi khusus diantaranya kawasan industri perikanan area, industri manufaktur area, industri parawisata area, industri pertanian area,logistik are dan area publik,seperti tampak pada gambar 4.1 berikut.

Kabupaten Pulau Morotai terusmengalami perkembangan. Letaknya yang strategis karena merupakan wilayah perbatasan, berdampak pada pergerakan yang semakin intensif dan terus mengalami peningkatan, begitu juga dengan kebutuhan ruang untuk mewadahi berbagai aktivitas penduduk juga semakin meningkat. Hal inidapat ditunjukkan dengan munculnya kawasan terbangun di sepanjang jalan arteri primer, bahkan disebelah selatan tampak kawasan terbangun yang cukup padat (mencapai 500 meter di sebelah kanan dan kiri jalan).

Gambar 4.3

Ringkasan Hasil Analisis Spasial Kabupaten Pulau Morotai Sebagai daerah Perbatasan dan KEK




Jurnal Penelitian Humano, Vol. 9 No. 2 Edisi November 2018

\section{Analisis Ekonomi Wilayah Morotai}

Perkembangan ekonomi suatu wilayah ditandai dengan adanya besaran pendapatan daerah. Untuk mengidentifikasi peranan perekonomian suatu daerah terhadap wilayah yang lebih luas, digunakan parameter besaran kontribusi pendapatan daerah tersebut dalam konstelasi yang lebih luas. Pendapatan daerah yang dimaksud ditunjukkan oleh angka Produk Domestik Regional Bruto (PDRB) yang merepresentasikan besarnya nilai tambah produksi total suatu daerah yang dinyatakan dalam satuan uang (rupiah). Dengan menghitung kontribusi PDRB Kabupaten Pulau Morotai terhadap Provinsi Maluku Utara, maka dapat diketahui peranan perekonomian Kabupaten Pulau Morotai ini dalam mendukung perekonomian Kabupaten Pulau Morotai.

Dengan melihat angka kontribusi PDRB berdasarkan harga konstan 2010, dalam rentang waktu 5 tahunya itu berawal dari tahun 2013-2016 peranan perekonomian Kabupaten Pulau Morotai terhadap perekonomian Provinsi Maluku Utara secara umum menunjukkan kecenderungan yang menurun walaupun tidak signifikan dari tahun ke tahun, kenaikan persentase kontribusi Kabupaten Pulau Morotai hanya terjadi 2 kali yaitu ditahun 2003 dan tahun 2005.

Berdasarkan hasil analisis diatas, Kabupaten Pulau Morotai menyumbangkan kontribusi PDRB rata-rata pertahun sebesar $2,32 \%$ dalam mengembangkan kondisi perekonomian di Provinsi Maluku Utara. Kontribusi tersebut didominasi oleh sektor pertanian dan sektor perangkutan dan komunikasi. Hasil tersebut dapat disimpulkan bahwa peranan Kabupaten Pulau Morotai dalam mendukung aktivitas perekonomian di Provinsi Maluku Utara masih tergolong rendah.

\section{Laju Pertumbuhan Ekonomi}

Pertumbuhan ekonomi merupakan salah satu indikator penilaian keberhasilan pembangunan di suatu wilayah. Pertumbuhan ekonomi berarti peningkatan kapasitas produksi dalam suatu perekonomian secara berkesinambungan yang diwujudkan dengan meningkatnya pendapatan nasional. Dengan tingkat pertumbuhan ekonomi yang cukup tinggi diharapkan produktivitas dan pendapatan masyarakat akan meningkat melalui penciptaan lapangan kerja dan kesempatan berusaha. Pada tahun 2015, pertumbuhan ekonomi di Pulau Morotai sebesar 6,13 persen dibanding tahun sebelumnya. Sedangkan pada tahun 2014 pertumbuhan ekonomi sebesar 6,19 persen dan pada tahun 2013 sebesar 6,05 persen. Hal tersebut menunjukan bahwa dari tahun ke tahun, pertumbuhan ekonomi di Pulau Morotai terus meningkat, namun pada tahun 2015 mengalami perlambatan.

Kategori lain yang mengalami perlambatan dalam pertumbuhan ekonomi yaitu kategori pertambangan dan penggalian (4,90 persen), Industri pengolahan (4,23 persen), Perdagangan Besar dan eceran (8,81 persen), Penyedia Akomodasi dan makan Minum (6,11 persen), dan kategori Informasi komunikasi (7,32 persen). Berdasarkan Tabel 1.2, pertumbuhan ekonomi meningkat dibeberapa kategori, yaitu kategori pengadaan listrik dan gas $(26,35$ persen), Pengadaan air, pengelolaan sampah, limbah dan daur ulang $(8,37$ persen), kategori Kontruksi (10,83 persen), kategori Transportasi dan 
Jurnal Penelitian Humano, Vol. 9 No. 2 Edisi November 2018

Pergudangan (7,91 persen), kategori Jasa Keuangan dan Asuransi (18,82 persen), Kategori Real estate (3,54 persen), Kategori Jasa Perusahaan (6,04 persen), administrasi Pemerintahan, Pertahanan dan Jaminan sosial wajib (8,21 persen), dan kategori jasa-jasa lainnya (5,71persen).

\section{Sektor Basis Kabuaten Pulau Morotai}

Sektor lapangan usaha merupakan media aktivitas penyelenggaraan proses pembangunan yang bisa dilaksanakan oleh pemerintah guna mencapai tujuan mensejahterakan kehidupan penduduknya. Oleh karenanya pertumbuhan sektoral itu menjadi penting, karena dari sektor-sektor itulah seluruh potensi yang dimiliki daerah dapat diberdayakan untuk memberikan kontribusi terhadap kebutuhan penyelenggaraan pembangunan. Dalam upaya pengembangan sektor ekonomi guna meningkatkan perekonomian daerah, diperlukan juga informasi dan pemahaman terhadap sektor yang menjadi sektor unggulan. Sektor unggulan perlu diidentifikasi sebagai bahan pertimbangan dalam menyusun rencana pengembangan sektor. Untuk mengidentifikasi suatu sektor tergolong unggulan atau bukan, analisisnya tidak hanya didasarkan pada besar kontribusi masing-masing sektor terhadap perekonomian, melainkan memerlukan beberapa pendekatan/analisis lain yang bisa memberikan gambaran yang lebih jelas.

Suatu sektor unggulan tidak hanya memiliki kontribusi terbesar terhadap perekonomian, tetapi memiliki tingkat kompetitif yang tinggi dibandingkan sektor lain serta memiliki kinerja yang baik. Ekonomi basis merupakan analisis untuk mengetahui sektor-sektor yang berpengaruh besar terhadap pertumbuhan perekonomian di suatu wilayah. Untuk mengetahui sektor yang berpengaruh kuat terhadap perkembangan ekonomi suatu wilayah digunakanlah metode LQ (Location Quotient) yang dapat dilihat pada Tabel 4.4.

Tabel 4.4. Nilai LQ setiap sector usaha di kabupaten pulau Morotai tahun 2013-2016(dalam jutaan rupiah

\begin{tabular}{|c|c|c|c|c|c|c|}
\hline \multirow{2}{*}{ Lapangan Usaha } & \multicolumn{2}{|c|}{2013} & \multirow[b]{2}{*}{ LQ } & \multicolumn{2}{|c|}{2016} & \multirow[b]{2}{*}{ LQ } \\
\hline & $\begin{array}{l}\text { Kab. Pulau } \\
\text { Morotai }\end{array}$ & $\begin{array}{c}\text { Provinsi } \\
\text { Malut }\end{array}$ & & $\begin{array}{l}\text { Kab. Pulau } \\
\text { Morotai }\end{array}$ & $\begin{array}{c}\text { Provinsi } \\
\text { Malut }\end{array}$ & \\
\hline Pertnian & 4.291 .8 & $5.520,4$ & 0,87 & $5,664$. & $6.186,4$ & 0,91 \\
\hline Pertambangan & 518.9 & $2.563,1$ & 9,97 & 634.5 & $2.245,7$ & 9,56 \\
\hline Industri Pengolahan & 133.4 & $1.088,6$ & 0.22 & 166.2 & $1.256,3$ & 0.24 \\
\hline Listrik Gas dan Air Minum & 11,03 & 17,4 & 1.40 & 14,2 & 20,3 & 1.76 \\
\hline Bangunan & 47,01 & 93,0 & 1.34 & 87,02 & 109,0 & 1.45 \\
\hline $\begin{array}{l}\text { Perdagangan, } \\
\text { Hotel dan Restoran }\end{array}$ & 134.78 & $3.387,0$ & 0.80 & 321.06 & $3.982,5$ & 0.76 \\
\hline Pengankutan dan Konsumsi & 346.09 & $1.201,4$ & 6.03 & 529.81 & $1.438,8$ & 6.63 \\
\hline
\end{tabular}


Jurnal Penelitian Humano, Vol. 9 No. 2 Edisi November 2018

\begin{tabular}{|l|c|c|c|c|c|c|}
\hline $\begin{array}{l}\text { Keuangan, Persewaan dan Jasan } \\
\text { Perusahaan }\end{array}$ & 227.94 & 631,3 & 1.13 & 322.80 & 705,9 & 1.20 \\
\hline Jasa-jasa & 377.07 & $3.509,7$ & 1.30 & 671.02 & $4.128,8$ & 1.44 \\
\hline
\end{tabular}

Keterangan:

Nilai LQ $<1$, berarti daerah yang bersangkutan mempunyai kecenderungan untuk impor dari daerah lain.

Nilai $L Q=1$, berarti daerah yang bersangkutan mampu mencukupi daerah sendiri dalam kegiatan tertentu.

Nilai LQ > 1, berarti daerah yang bersangkutan mampu memenuhi pada sektor tertentu dan memiliki kecenderungan ekspor ke daerah lain

Berdasarkan hasil analisis LQ di atas maka dapat disimpulkan sektor basis di Kabupaten Pulau Morotai adalah sektor pertambangan, pengangkutan dan komunikasi, listrik, gas dan air minum, bangunan, jasa-jasa, keuangan, persewaan dan jasa perusahaan. Sedangkan yang termasuk sektor non basis adalah sektor pertanian, industri pengolahan, sektor perdagangan, hotel dan restoran. Berdasarkan hasil pengolahan dengan menggunakan metode LQ, diperoleh beberapa alternatif sektor yang berpotensi menjadi sektor unggulan yaitu sektor pertambangan dengan nilai LQ paling tinggi dibandingkan sektor lainnya. Kemudian sektor kedua yang berpotensi menjadi sektor asi tinggi dan mampu memenuhi pada sektor tertentu dan memiliki kecenderungan ekspor unggulan adalah pengangkutan dan komunikasi. Dengan nilai LQ yang relatif besar, maka kedua sektor tersebut merupakan sektor basis dan memiliki tingkat spesialis ke daerah lain, khususnya sektor pengangkutan dan komunikasi terus mengalami peningkatan yang cukup signifikan hingga tahun 2016. Dengan memperhatikan analisis di atas, maka secara umum terlihat bahwa sektor-sektor yang berpotensi menjadi sektor unggulan di Kabupaten Pulau Morotai adalah sektor pertambangan, pengangkutan dan komunikasi, serta listrik, gas dan air minum. Sedangkan sektor lainnya seperti industri pengolahan, keuangan, persewaan dan jasa perusahaan cenderung kurang kompetitif dan mempunyai kecenderungan untuk impor dari daerah lain, sehingga kurang dapat bersaing dengan wilayah di sekitarnya.

\section{Kinerja Sektor Perekonomian Kabupaten Pulau Morotai}

Sektor unggulan merupakan dambaan bagi setiap daerah, karena dengan sektor unggulan itu suatu daerah akan berpeluang lebih besar untuk mengembangkan potensi yang ada menuju kemandirian daerah. Untuk mengetahui sektor unggulan pada Kabupaten Pulau Morotai, akan dijelaskan melalui metode ShiftShare. Metode tersebut merupakan salah satu metode yang dapat digunakan untuk menggambarkan kinerja perekonomian di suatu wilayah, sehingga dengan penjelasan itu dapat pula diketahui komposisi perekonomian wilayah dan pergeseran relatif struktur sektor lapangan usaha dalam perekonomian. Dengan demikian sektor unggulan daerah dalam kaitannya dengan kondisi perekonomian dalam wilayah yang lebih luas akan teridentifikasi.

Selanjutnya

untuk

mengidentifikasi sektor unggulan lapangan usaha dari suatu kondisi perekonomian di Kabupaten Pulau Morotai berpedoman pada:

- KPPW (+) ; KPP (+) : sektor lapangan usaha wilayah unggul

- KPPW (+) ; KPP (-) : sektor lapangan 
Jurnal Penelitian Humano, Vol. 9 No. 2 Edisi November 2018

usaha wilayah cukup unggul

- KPPW (-) ; KPP (+) : sektor lapangan usaha wilayah mengalami kemunduran

- KPPW (-) ; KPP (-) : sektor lapangan usaha wilayah sangat mengalami kemunduran

Berdasarkan pada perhitungan analisis shift share untuk Kabupaten Pulau Morotai (Tabel 4.5), sektor listrik, gas, dan air bersih, pengangkutan dan komunikasi, industry pengolahan dan jasa-jasa, berkemampuan tumbuh pesat dan dimungkinkan berpengaruh secara positif terhadap peningkatan perekonomian dan pendapatan Kabupaten Pulau Morotai.

Hal tersebut ditunjukkan dari nilai positif yang dihasilkan antara KPK dan KPP. Sedangkan sector pertanian, pertambangan dan keuangan, persewaan dan jasa perusahaan masih merupakan sektor yang mengalami kemunduran karena nilai negative yang dihasilkan antara komponen KPP dan KPPW.

Tabel 4.5 Hasil Pengolahan Shift-Share Tahun 2013-2016 (PDRB Dalam Jutaan Rupiah)

\begin{tabular}{|c|c|c|c|c|c|c|c|c|}
\hline \multirow{2}{*}{ LAPANGAN USAH } & \multicolumn{2}{|c|}{ PROVINSI MALUT } & \multicolumn{2}{|c|}{ Kab. Pulau Morotai } & \multicolumn{3}{|c|}{ KOMPONEN } & \multirow[b]{2}{*}{ PEK } \\
\hline & 2003 & 2007 & 2003 & 2007 & KPW & KPP & KPPW & \\
\hline Pertanian & $680,524.12$ & $849,193.57$ & $14,547.64$ & $17,561.12$ & 0.27 & - & - & 0.21 \\
\hline Pertambangan & $28,466.71$ & $25,913.38$ & $6,960.05$ & $5,607.11$ & 0.27 & 0.03 & 0.04 & \\
\hline Industri Pengolahan & $516,452.57$ & $685,364.13$ & $2,848.32$ & $3,724.75$ & 0.27 & 0.05 & - & 0.31 \\
\hline $\begin{array}{l}\text { Listrik, Gas, dan Air } \\
\text { Minum }\end{array}$ & $4,289.55$ & $6,345.96$ & 147.6 & 252.87 & 0.27 & 0.21 & 0.23 & 0.71 \\
\hline Bangunan & $73,093.73$ & $92,983.03$ & $2,400.49$ & 3.053 .68 & 0.27 & 0.00 & 0.00 & 0.27 \\
\hline $\begin{array}{l}\text { Perdagangan, Hotel dan } \\
\text { Restoran }\end{array}$ & $292,595.98$ & $373,739.99$ & $5,715.19$ & 6.447 .41 & 0.27 & 0.00 & 0.15 & 0.13 \\
\hline $\begin{array}{l}\text { Pengangkutan dan } \\
\text { Komunikasi }\end{array}$ & $41,851.60$ & $55,435.31$ & $6,192.69$ & $8,324.68$ & 0.27 & 0.05 & 0.02 & 0.34 \\
\hline $\begin{array}{l}\text { Keuangan, Persewaan } \\
\text { dan Jasa Perusahaan }\end{array}$ & $56,713.34$ & $68,452.55$ & 1.573 .25 & $1,859.49$ & 0.27 & 0.07 & 0.03 & 0.18 \\
\hline Jasa-jasa & $156,118.84$ & $199,174.77$ & $4,994.11$ & $6,508.40$ & 0.27 & 0.00 & 0.03 & 0.30 \\
\hline Jumlah & $1,850,196.44$ & $2,356,602.68$ & $45,379.38$ & $53,339.51$ & & & & \\
\hline
\end{tabular}

Sumber: Hasil Analisis, 2017

Dalam konteks mundurnya sektor pertanian dalam kinerja perekonomian wilayah, jika dibandingkan dengan kawasan perbatasan Negara tetangga, terlihat adanya ketimpangan ekonomi yang cukup signifikan. Kawasan perbatasan yang kaya akan SDA seharusnya merupakan kawasan yang maju dan sejahtera,namun kenyataannya menjadi sangat tertinggal. Padahal jika dicermati, terjadi aktivitas ekonomi yang cukup tinggi khususnya yang terkait dengan pertanian.

Pemerintah Morotai dapat 
Jurnal Penelitian Humano, Vol. 9 No. 2 Edisi November 2018

mengarahkan program pembangunannya pada sektor-sektor yang memiki keunggulan tersebut, sehingga pada masanya akan tumbuh menjadi sektor yang mampu menyediakan lapangan kerja bagi penduduk yang belum memperoleh lapangan pekerjaan. Adapun arahan kesempatan kerja berada pada sector listrik, gas, dan air bersih, pengangkutan dan komunikasi, serta jasa-jasa. Dalam upaya untuk mengidentifikasi sector yang berpotensi menjadi sektor unggulan,maka dapat diperoleh dengan mengkombinasikan komponen KPP dengan KPPW. Untuk lebih jelas perhatikan matrik pada Gambar4.4 berikut ini.

Gambar 4.4 Pengelompokan sektor berdasarkan analisis Shift-share 2013-2016

\begin{tabular}{|c|c|c|c|}
\hline & \multicolumn{2}{|c|}{ KomponenPertumbuhanSektoralKabupatenMorotai (KPP) } \\
\hline & & Positif(+) & Negatif(-) \\
\hline 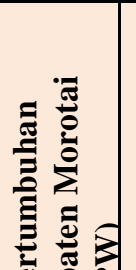 & & $\begin{array}{l}\text { Sektor unggul: } \\
\text {-listrik,gas dan air bersih } \\
\text {-bangunan } \\
\text {-pengangkutan dan komunikasi } \\
\text {-jasa-jasa (Parawisata), dan Hotel }\end{array}$ & $\begin{array}{l}\text { Sektor agak unggul: } \\
\text { - Tidak ada }\end{array}$ \\
\hline 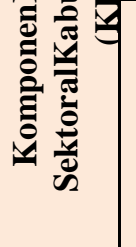 & 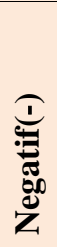 & $\begin{array}{l}\text { Sektor agak mundur: } \\
\text { - Industri pengolahan } \\
\text { - Perdagangan, dan jasa } \\
\text { perusahaan }\end{array}$ & $\begin{array}{l}\text { Sektor mundur: } \\
\text { - Pertanian } \\
\text { - Pertambangan } \\
\text { - Keuangan,persewaan, dan jasa lainnya }\end{array}$ \\
\hline
\end{tabular}

Sumber:Hasil Analisis, 2017

Berdasarkan hasil analisis dengan menggunakan metode Shift-share ini, diperoleh beberapa hal sebagai berikut:

1. Sektor unggulan dalam perekonomian Kabupaten Pulau Morotailebih didominasi oleh sektor-sektor yang tergolong kepada sector tersier yang dalam hal ini ditunjukkan oleh sektor listrik, gas, dan airbersih, bangunan, pengangkutan dan komunikasi, sertajasa-jasa (Parawisata dan Perhotelan)

2. Sektor agak mundur adalah industri pengolahan, perdagangan, hotel, dan jasa perusahaan.

3. Kemudian sektor pertanian, pertambangan dan keuangan, persewaan, dan jasa menjadi sector yang mundur di Kabupaten Pulau Morotai

Berdasarkan analisis LQ sebelumnya, sector pertambangan dan sektor keuangan dan jasa merupakan sector yang berpotensi untuk menjadi sector unggulan. Adanya pengaruh eksternal yang negative dan pengelolaan yang kurang optimal dapat mengakibatkan sector ini berada pada sector yang mundur, sehingga perlu dilakukan peningkatan atau perbaikan secara intensif untuk menjadikan kedua sector ini menjadi kompetitif.

Faktor-faktor internal yang mempengaruhi kinerja perekonomian di Kabupaten Pulau Morotai antara lain kurangnya sumberdaya manusia terlatih 
Jurnal Penelitian Humano, Vol. 9 No. 2 Edisi November 2018

maupun terdidik yang mampu mengolah sumber daya lokal yang ada secara optimal. Kemudian kurangnya upaya pemerintah dalam menciptakan iklim investasi yang kondusif untuk merangsang kinerja dan pertumbuhan ekonomi. Sedangkan faktor eksternal yang berpengaruh misalnya kondisi keamanan dan iklim kebijakan investasi yang tidak stabil mempengaruhi calon-calon investor yang ingin menanamkan modalnya diMorotai.

Adanya kebijakan pemerintah pusat menjadikan Pulau Morotai sebagai Kawasan Ekonomi Khusus (KEK) maka sector basis akan berkembang dan pada gilirannya juga akan mendorong perkembangan sector non basis wilayah terkait. Dengan adanya kebijakan itu tentunya akan menghambat sektor-sektor yang berpotensi untuk berkembang dan secara tidak langsung akan berpengaruh terhadap aktivitas perniagaan dimana kegiatan eksporimpor merupakan salah satu pendukung dalam aktivitas tersebut. Keterkaitan antarsektor mengarah pada kondisi yang lebih baik, dengan perkembangan yang paling baik pada sector jasa (parawisata, hotel dan restoran).

Berdasarkan nilai KPP dan KPPW pada analisis perekonomian, industri pengolahan Kabupaten Pulau Morotai termasuk dalam sector lapangan usaha yangcukup unggul. Hal tersebut mengindikasikan bahwa sector ini sangat berpotensi untuk dikembangkan sebagai sector unggulan(leadingsector). Tidak adanya tindak lanjut dari pengolahan hasil panen pertanian merupakan salah satu hambatan yang menjadikan nilai jual komoditas tersebut rendah. Adanya rencana penciptaan usaha industry pengolahan yang berbasis pada hasil pertanian sangat membuka peluang pengembangan lebih lanjut khususnya dalam meningkatkan nilai jual komoditas pertanian sehingga mampu bersaing dengan komoditas sejenis diwilayah lainnya.

\section{Sektor Prioritas}

Analisis ini menggunakan hasil analisis sebelumnya, yaitu LQ dan Shift Share. Komponen pergeseran bersih (PB) yang didapatkan dari penjumlahan atas KPP dan KPPW digabungkan dengan perhitungan LQ, sehingga sektor-sektor tersebut dapat diidentifikasikan dalam kuadran tertentu. Selengkapnya dapat dilihat di Tabel 4.5dan Gambar 4.5. Berdasarkan analisis LQ dan ShiftShare maka dapat diambil kesimpulan, bahwa sebaiknya pengembangan sector lapangan usaha dikonsentrasikan pada sektor-sektor yang basisnya sudah kuat seperti listrik, gas ,dan air bersih, pengangkutan dan komunikasi, serta jasa-jasa. Namun demikian, sektor-sektor lain yang sudah tumbuh dan kemungkinan memiliki kemampuan dalam menunjang kemajuan perekonomian seperti pertanian, industry pengolahan, pertambangan, dan bangunan dapat lebih berkembang meningkatkan kinerja perekonomian secara keseluruhan. Sementara sector lain yang bukan merupakan sector basis tetap diupayakan agar pertumbuhannya terhadap kontribusi PDRB terus mengalami kemajuan. 
Jurnal Penelitian Humano, Vol. 9 No. 2 Edisi November 2018

Tabel4.5. Nilai pergeseran bersih (PB) dan locationquotient Persektordi kabupaten pulau morotai

\begin{tabular}{|c|c|c|c|c|c|c|c|c|c|}
\hline \multirow[t]{2}{*}{ No. } & \multirow[t]{2}{*}{ LAPANGAN USAHA } & \multicolumn{2}{|c|}{ KOMPONEN } & \multicolumn{2}{|c|}{$\mathrm{PB}(\mathrm{KPP}+\mathrm{KPPW})$} & \multirow[t]{2}{*}{ KET. } & \multicolumn{2}{|c|}{ LQ } & \multirow[t]{2}{*}{ KET. } \\
\hline & & KPP & KPPW & & & & & & \\
\hline 1 & Pertanian & -0.03 & -0.04 & -0.07 & $\mathrm{~PB}<0$ & Mundur & 0.91 & $L Q<1$ & Non \\
\hline 2 & Portamhang & 0.36 & 010 & 0.46 & $P R<0$ & Mundur & 956 & $10>1$ & Basi: \\
\hline & & & & & & & 024 & $0<1$ & \\
\hline 3 & Industri Pengolahan & 0.05 & -0.02 & 0.03 & $P B>0$ & Progresit & 0.24 & Lu<1 & $\begin{array}{l}\text { Non } \\
\text { Basi }\end{array}$ \\
\hline 4 & Listrik,Gas dan Air Minum & 0.21 & 0.23 & 0.44 & $\mathrm{~PB} \times 0$ & Progresif & 1.76 & $L Q>1$ & Basis \\
\hline 5 & Bangunan & 0.00 & 0.00 & 0 & $\mathrm{~PB}<0$ & Mundur & 1.45 & $L Q>1$ & Basis \\
\hline \multirow[t]{2}{*}{6} & Perdagangan, Hotel dan & 0.00 & -0.15 & -0.15 & $P B<0$ & Mundur & 0.76 & $L Q<1$ & Non \\
\hline & Restoran & & & & & & & & Basis \\
\hline 7 & Pengangkutan dan Komunikasi & 0.05 & 0.02 & 0.07 & $\mathrm{~PB} \times 0$ & Progresif & 6.63 & LQ $>1$ & Basi: \\
\hline \multirow[t]{2}{*}{8} & Keuangan, Persewaan \& Jasa & -0.07 & -0.03 & -0.10 & $\mathrm{~PB}<0$ & Mundur & 1.20 & $L Q>1$ & Basi: \\
\hline & Perusahaan & & & & & & & & \\
\hline 9 & Jasa-jasa & 0.00 & 0.03 & 0.03 & $\mathrm{~PB} \times 0$ & Progresif & 1.44 & $L Q>1$ & Basi: \\
\hline
\end{tabular}

Sumber : Hasil Analisi, 2017

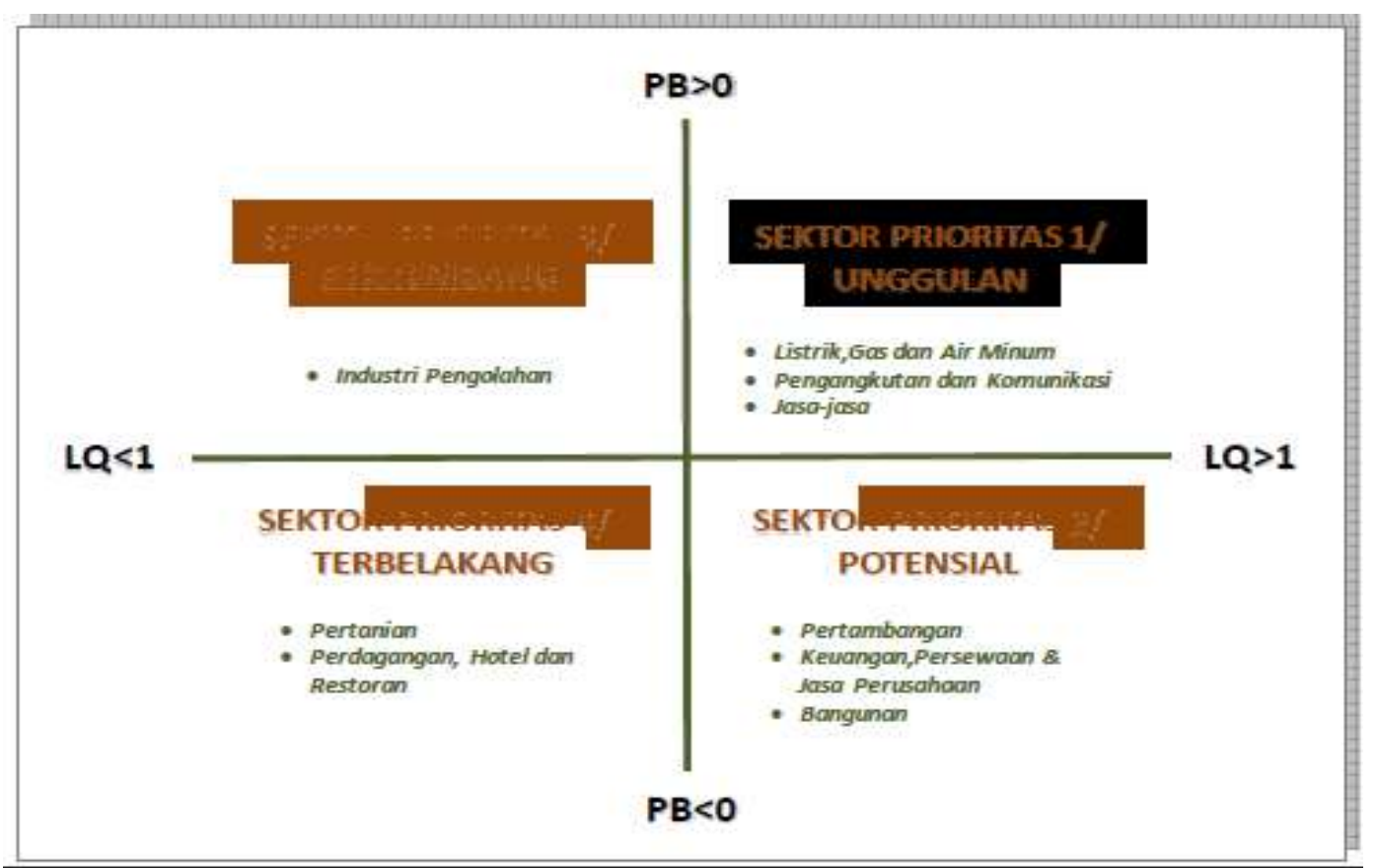

Hasil perhitungan PB dan LQ diatas, selanjutnya dilakukan plotting pada kuadran tertentu dalam menentukan sektor unggulan di Kabupaten Pulau Morotai 
Jurnal Penelitian Humano, Vol. 9 No. 2 Edisi November 2018

KONTRIBUSISEKTOR EKONOMI:

Rata-rata kontribusiKabupaten Pulau Morotai terhadapProvinsi Maluku Utarasebesar2,32\%, Fluktuatifdancenderung menurun.

\section{LAJU PERTUMBUHAN EKONOMI:} Rata-rata pertumbuhan sebesar 5,88\% (tahun 2013-2016). Pertumbuhan sektoral tertinggi sektor listrik, gas dan air minum(10,38\%), pengangkutan dan komunikasi $(7,60 \%)$, industri pengolahan $(7,47 \%)$.Sedangkan pertumbuhan minus terdapat pada sektor pertambangan $(-2$, $27 \%$ ).

SEKTOR BASIS: Sektor basis di Kabupaten Pualu Morotai adalah sektor pertambangan, pengangkutan dan komunikasi, listrik, gas dan air minum, bangunan, jasa-jasa, keuangan, persewaan dan jasa perusahaan. Sektor non basis adalah sektor pertanian, industri pengolahan, dan perdagangan, serta hotel dan restoran

\section{KINERJA PEREKONOMIAN:}

Pertumbuhan Ekonomi sektoral tertinggi pada Listrik, gas dan air minum, perangkutan dan komunikasi, dan industr pengolahan. Sektor maju: sektor listrik, gas, dan air bersih, bangunan, pengangkutan dan komunikasi serta jasa-jasa. Agak Mundur: industri pengolahan, perdagangan, hotel, dan jasa perusahaan - Mundur: pertanian, pertambangan dan keuangan, persewaan, dan jasa

SEKTORP RIORITAS: Listrik, Gas danAir Minum, - Perangkutandan Komunikasi, Jasa-Jasa.

\section{KESIMPULAN DAN REKOMENDASI}

Bagian ini akan membahas tentang kesimpulan dan rekomendasi tentang strategi pengembangan wilayah perbatasan
Kabupaten Pulau Morotai dalam memacu pertumbuhan ekonomi.

\section{Kesimpulan}

1. Tinjauan terhadap aspek spasial menunjukkan perubahan yang relatif kecil dari sisi penggunaan lahan bagi pertumbuhan aktivitas ekonomi. Polarisasi penduduk dan struktur ruang yang terbentuk lebih disebabkan oleh kondisi topografi dan infrastruktur jalan yang terbangun, khususnya jalan utama menuju pintu perbatasan. Kondisi ini memerlukan perhatian, terkait dengan peran Kabupaten Pulau Morotai sebagai KEK Nasional yang berfungsi ekonomi sekaligus menjaga fungsi lindung yang ada di kawasan perbatasan. Upaya dalam memacu pertumbuhan ekonomi tentunya dihadapkan pada sisi konservasi lingkungan dengan fungsi lindung kawasan. Prinsip pengembangan wilayah yang berkelanjutan (sosial-ekonomi lingkungan) sangat penting untuk diterapkan dalam konteks ini.

2. Pertumbuhan ekonomi dapat terlihat dari besarnya laju pertumbuhan ekonomi rata-rata $(5,88 \%)$, dibandingkan dengan laju pertumbuhan penduduk $(1,18 \%)$. Selain itu, secara basis ekonomi, hampir seluruh sektor adalah sektor basis kecuali sektor pertanian, industri pengolahan dan perdagangan. Tinjauan secara basis ekonomi tersebut menunjukkan adanya pertumbuhan ekonomi, karena sektor basis dapat mendorong majunya perekonomian wilayah perbatasan. Potensi ini dapat berkembang dengan lebih baik tentunya dengan dukungan multisektor dan kebijakan yang kondusif, kondisi ini merupakan modal awal yang penting bagi pengembangan wilayah perbatasan 
Jurnal Penelitian Humano, Vol. 9 No. 2 Edisi November 2018

yang diharapkan menjadi motor pertumbuhan bagi wilayah sekitarnya

3. Tinjauan terhadap kinerja perekonomian menunjukkan bahwa sektor listrik, gas dan air minum, sektor perangkutan dan komunikasi, dan sektor jasa-jasa merupakan sektor-sektor yang berkinerja maju. Hal ini terkait dengan fungsi kawasan perbatasan dengan aktivitas ekonomi yang mulai menggeser peran pertanian dalam perekonomian wilayah. Dinamika perkembangan kawasan perbatasan berimplikasi terhadap sektor-sektor yang berkembang, termasuk berkembangnya sektor sekunder dan tersier yang diharapkan mampu memacu pertumbuhan ekonomi lebih baik lagi.

4. Strategi pengembangan kawasan perbatasan Kabupaten Pulau Morotai terkait dengan upaya dalam memacu pertumbuhan ekonomi antara lain adalah: mendorong regulasi yang kondusif dan operasional bidang pengembangan perekonomian kawasan perbatasan, menyusun road map penataan ruang yang efektif dan operasional, melakukan improvisasi pengembangan infrastruktur yang responsif terhadap kebutuhan (hard \& soft infrastructure), meningkatkan peran sektor unggulan dan mendorong sektor lainnya dalam pertumbuhan, meningkatkan perhatian pada sustainabilitas pembangunan dan pengembangan Sumber Daya Manusia, fasilitasi perdagangan yang sifatnya internal dan eksternal.

\section{DAFTAR PUSTAKA}

Adisasmita, R. 2005. Dasar-Dasar Ekonomi Wilayah. Yogyakarta: Graha Ilmu.

Akaha, T. and Anna, V. (eds). 2015.
Crossing National Borders: Human Migration Issues in Northeast Asia. Japan: United Nations University Press.

Bendavid - Val, A. 1991. Regional and Local Economic Analysis for Practicioners. Fourth Edition. New York: Preager.

Berg, E. and Ehin, P. 2006. "What Kind of Border Regime is in the Making?: Towards

a Differentiated and Uneven Border Strategy". Cooperation and Conflict,2006 pp. 4153.[Online]. Available: http://cac.sagepub.com. [April 29, 2008].

Branch, M. C. 1998. Comprehensive Planning for the 21 st Century: General, Theory \& Principles. Preager: London.

Couldry, N .2014. In the Place of a Common Culture, What? Cultural Studies Vol. 26: 14.

Mercado, S. 2002. "The Right to Escape". Ephemera4 (3): pp. 267-75.

McIntosh, M. 2001. Marks and Spencer: Global Companies in the Twentieth Century. Routlege.

Niebuhr, A and Stiller, S. 2011. Integration Effect in Border Regions - A Survey of conomic Theory and Empirical Studies. HWWA Discussion Paper. Hamburg.

Peraturan Pemerintah Nomor 50, Tahun 2014. Tentang Kawasan Ekonomi Khusus Pulau Morotai Kabuapen Morotai Provinsi Maluku Utara

Ratti, R. 2013. How Can Existing Barrier and Burdens Effect of Borders: A Theoretical Approach. in Cappellin, R. and Batey, P. J. W. 
Jurnal Penelitian Humano, Vol. 9 No. 2 Edisi November 2018

(eds). Regional Network, Border

Region and European

Integration. pp. 60-69. London:

Pion

Tarigan, R. 2004. Ekonomi Regional Teori dan Aplikasi. Jakarta: Bumi Aksara.

Van Well, L. 2015. Cross-Border Typologies in the Enlargement Area. Results from the ESPON 1.1.3 Report. Enlargement of the European Union and its Polycentric Spatial Structure. Royal Institute of Technology.

Wu, C. T. 2011. Cross-Border Development in a Changing World: Redefining Regional Development Policies. In Edgington, D.W., Fernandez, A. L. and Hoshino, C. (eds). New Regional Development

Paradigm.Vol. 2. London: Greenwood Press. 